\title{
Pedicle morphometry of thoracic and lumbar vertebrae in adolescent idiopathic scoliosis
}

\author{
Adolesan idiopatik skolyozda torasik ve lomber omurların pedikül \\ morfolojisi
}

İsmail Emre KETENCi ${ }^{1}$, Hakan Serhat YANIK ${ }^{1}$, Şevki ERDEM ${ }^{2}$

\begin{abstract}
In adolescent idiopathic scoliosis surgery (AIS) thorough knowledge of the morphometry of deformed vertebrae is important for safe pedicle screw instrumentation and correction of deformities. This study aimed to evaluate the morphometry of each vertebra in AIS patients based on chord length (CL), transverse pedicle width (TPW) and transverse pedicle angle (TPA). Preoperative thoracolumbar computed tomography (CT) images of 81 AlS patients that were retrospectively evaluated. Mean age of the patients was 15.1 years, while 64 of them were female and 17 were male. Digital measurements of CL, TPW and TPA were performed for concave and convex pedicles of all thoracic and lumbar levels. Values of concave and convex sides were compared. CL was shortest at T1 and longest at $L 5 . C L$ values on the concave side were higher than those on the convex side with significant difference at T9 and L3 levels $(p<0.05)$. Consistently smaller TPW values were measured on the concave side, however significant difference was only found at T8 and T9 levels $(p<0.05)$. Narrowest pedicles were observed at T5 level. Highest and lowest values of TPA were observed at T1 and T12 levels respectively. Values were higher on the concave side with significant difference at $T 7, T 8$ and $L 3$ levels $(p<0.05)$. Concave pedicles are generally longer, thinner and more medially inclined in the transverse plane. These findigs are distinct in the apical region but may show variations among patients. Routine preoperative CT examination can give important information about the individual bone structure of each patient.
\end{abstract}

Keywords: Adolescent idiopathic scoliosis, pedicle morphology, chord length, transverse pedicle width, transverse pedicle angle öz

\begin{abstract}
Adolesan idiyopatik skolyoz (AIS) cerrahisinde güvenli enstrümantasyon ve düzeltme yapılabilmesi için deforme omurların morfolojisinin ayrıntıı olarak bilinmesi önemlidir. Bu çalışmada, kord uzunluğu (KU), transvers pedikül genişliği (TPG) ve transvers pedikül açıSI (TPA) baz alınarak, AIS hastalarının her bir omur morfolojisinin değerlendirilmesi amaçlanmıştır. AIS tanılı 81 hastanın ameliyat öncesi Bilgisayarlı Tomografi (BT) görüntüleri retrospektif olarak incelendi. Ortalama yaşı 15.1 olan hastaların 64'ü kadın, 17'si erkekti. Torasik ve lomber bölgedeki tüm omurların konkav ve konveks pediküllerine KU, TPG ve TPA ölçümleri dijital olarak uyguland. Konkav ve konveks taraflardaki değerler karşıllaştırıldı. KU T1'de en kısa, L5'te en uzun olarak ölçüldü. Konkav taraftaki KU değerleri konveks tarafa göre daha fazla bulunurken, T9 ve L3 seviyelerinde bu fark anlamlıydı $(p<0,05)$. TPG değerleri ise konkav tarafta daha düşük olarak ölçüldü, anlamlı fark T8 ve T9 seviyelerinde saptandı $(p<0.05)$. En dar pediküller T5 seviyesinde bulundu. TPA ölçümlerinin en yüksek ve en düşük değerleri sırasıyla $T 1$ ve T12 seviyelerindeydi. Konkav taraftaki değerler daha yüksek bulunurken, anlamlı fark $T 7, T 8$ ve L3 seviyelerinde saptandı $(p<0.05)$. Konkav taraftaki pediküller genel olarak daha uzun ve daha dar olup bunlarin transvers plandaki medial inklinasyonları da daha fazladır. Bu bulgular apikal bölgede daha belirgin olmakla beraber, hastadan hastaya farlıliklar gösterebilir. Ameliyat öncesi rutin BT taraması hastaya özgü kemik yapısı hakkında önemli bilgiler verebilir.
\end{abstract}

Anahtar kelimeler: Adolesan idiyopatik skolyoz, kord uzunluğu, transvers pedikül genişliği, transvers pedikül açısı

\section{INTRODUCTION}

Pedicle screws are getting more widely used in AIS surgery in order to correct the three-dimensional de- formity. To increase the effectivity of correction and to decrease correction loss, surgeons try to insert pedicle screws segmentally at every possible level ${ }^{1,2}$. For safe implantation of the screws a thorough know-

Received: 28.12 .2017

Accepted: 01.04.2018

${ }^{1}$ Haydarpasa Numune Education and Research Hospital, Department of Orthopaedics and Traumatology, Istanbul, Turkey

${ }^{2}$ Emsey Hospital, Department of Orthopaedics and Traumatology, Istanbul, Turkey

Yazışma adresi: İsmail Emre Ketenci, Haydarpasa Numune Education and Research Hospital, Department of Orthopaedics and Traumatology, Istanbul, Turkey

e-mail: emreket@yahoo.com 
ledge of the morphometry of scoliotic vertebrae is crucial. Therefore, many anatomic and radiologic studies have been performed in order to evaluate the dimensions and angles of vertebral structures in healthy as well as scoliotic spines ${ }^{3-8}$.

In addition to the generally known three-dimensional deformity, every AIS patient has individual intra- and intervertebral rotation as well as vertebral morphology 4 . Therefore we routinely perform multiplanar CT and magnetic resonance imaging in every AIS patient for preoperative planning.

The purpose of this study was to evaluate the vertebral morphometric parameters such as chord length, transverse pedicle width and transverse pedicle angle in AIS patients with respect to safe pedicle screw instrumentation.

\section{MATERIALS and METHODS}

\section{Patient Characteristics}

Hundred and thirty-two consecutive AIS patients that were treated with posterior segmental all pedicle screw instrumentation and fusion were recruited into this study, and retrospectively evaluated. Exclusion criteria included non-AIS patients aged $>20$ years with intraspinal or congenital pathology, and history of spine surgery. Patients who did not have good quality CT images were also excluded. Fifty-one patients were excluded according to above criteria. Of the remaining 81 patients 64 were female and 17 were male. Mean age of the patients was 15.1 years (range, $12-20$ years). The patients had Lenke type $1(n=33), 2(n=5), 3(n=6), 4(n=2), 5(n=23)$, and 6 $(n=12)$ AIS.

\section{Radiographic Measurements}

For preoperative evaluation 36-inch long casette anteroposterior (AP), lateral and AP bending radiographs, magnetic resonace imaging (MRI) and multiplanar computed tomography (CT) were performed in all patients routinely. During the CT examination, 0.6 $\mathrm{mm}$ axial cuts were taken throughout the thoracal and lumbar regions for morphometric analysis. From these sections, true axial images were reconstructed according to the tilt of each vertebra in coronal and sagittal planes (Figures 1 and 2). The true axial images were analyzed by measuring chord length, transverse pedicle width and transverse pedicle angle of concave and convex pedicles. Measurements were performed by an experienced spinal surgeon.

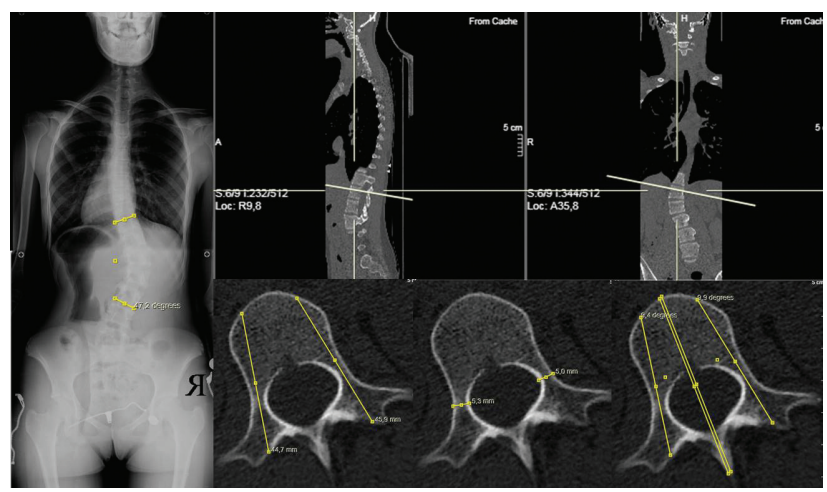

Figure 1. 14 year-old girl with Lenke type 5 scoliosis. The Cobb angle of the thoracolumbar curve is $\mathbf{4 7 . 2}$ degrees with the apex at L1. The true axial plane of L1 vertebra is determined according to its tilt in sagittal and coronal planes. CL, TPW and TPA are measured on this true axial image.

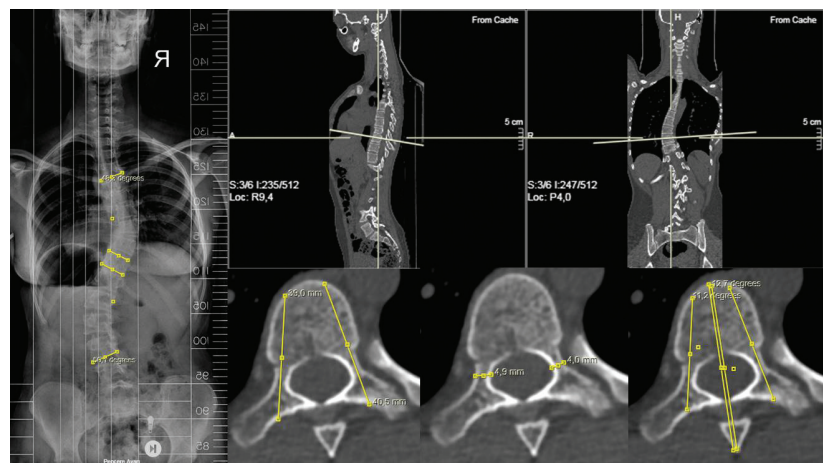

Figure 2. 16 year-old girl with Lenke type 6 scoliosis. Main thoracic and lumbar curves are measured as $\mathbf{4 8 . 3}$ and $\mathbf{5 0 . 1}$ degrees respectively. Measurements on the true axial image of the apical vertebra (T9) of the main thoracic curve are shown.

The distance from the most outer posterior cortex of the pedicle to the anterior cortex of the vertebral body with the long axis of the pedicle in the transverse plane was defined as the chord length. The transverse pedicle width was measured at the thinnest pedicle region between medial and lateral outer cortices of the pedicle. Transverse pedicle angle was 
measured between the long axes of the pedicle and the vertebral body (Figure 3).

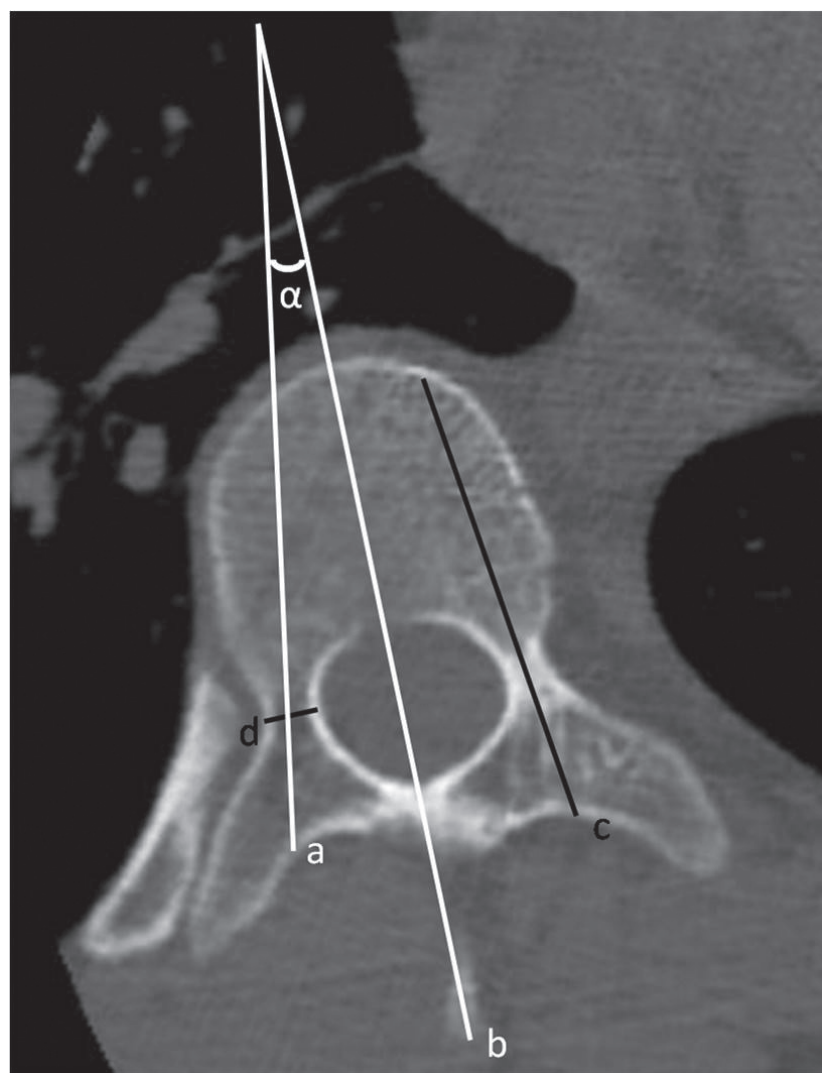

Figure 3. Axial CT image of T10 vertebra with illustrations of transverse pedicle angle $(\alpha)$, chord length $(c)$, and transverse pedicle width (d).

\section{Statistical Analysis}

All statistical analyses were conducted using SPSS for Windows (Version 21.0; IBM Corp. Armonk, NY, USA). Statistical comparisons between concave and convex sides were performed using the unpaired " $\mathrm{t}$ " test. A $p$ value of $<0.05$ was considered as statistically significiant.

\section{RESULTS}

A total of 1377 vertebrae of 81 patients were evaluated. Mean Cobb angles of the structural curves are given in Table 1. Mean chord length, transverse pedicle width and transverse pedicle angle values are given in Table 2.

The chord length was shortest at T1, increased gradually going down to lower lumbar levels, and was measured longest at L5. Chord lengths on the concave side were generally longer than those on the convex side, however the difference was insignificant at most levels. Significantly longer chord lengths were measured at the concave side of T9 and L3 levels $(p<0.05)$.

From T3 to L5 consistently smaller transverse pedicle width values were observed on the concave side, however significant difference was only found at T8 and T9 levels $(p<0.05)$. Narrowest pedicles were observed at T5, whereas largest transverse diameter was found at L5 level.

Highest and lowest values of transverse pedicle angle were observed at T1 and T12 levels respectively. Values were higher on the concave side compared to the corresponding convex pedicles except T1 level. Significant difference was found at T7, T8 and L3 levels (Table 1).

Table 1. Mean Cobb angles of the structural curves according to Lenke types.

\begin{tabular}{llll}
\hline Lenke Type & Proximal Thoracic Curve & \multicolumn{1}{c}{$\begin{array}{c}\text { Main Thoracic Curve } \\
\left({ }^{\circ}{ }^{\circ}\right)\end{array}$} & $\begin{array}{c}\text { Thoracolumbar/Lumbar Curve } \\
\left({ }^{\circ}\right)\end{array}$ \\
\hline 1 & - & $54.4 \pm 12.5$ & - \\
2 & $37.3 \pm 6.3$ & $50.1 \pm 9.5$ & $46.8 \pm 11.7$ \\
3 & - & $54.6 \pm 10.4$ & $61.5 \pm 8.5$ \\
4 & $44.5 \pm 5.5$ & $70.5 \pm 9.5$ & $44.9 \pm 7.4$ \\
5 & - & - & $57.4 \pm 14.6$ \\
6 & - & $42.1 \pm 7.8$ & \\
\hline
\end{tabular}


Table 2. Measurements of chord length, transverse pedicle width and transverse pedicle angle.

\begin{tabular}{|c|c|c|c|c|c|c|c|c|c|}
\hline \multirow[b]{2}{*}{ Level } & \multicolumn{3}{|c|}{ Chord length (mm) } & \multicolumn{3}{|c|}{ Transverse pedicle width (mm) } & \multicolumn{3}{|c|}{ Transverse pedicle angle $\left({ }^{\circ}\right)$} \\
\hline & Concave & Convex & $\mathbf{p}$ & Concave & Convex & $\mathbf{p}$ & Concave & Convex & $\mathbf{p}$ \\
\hline $\mathrm{T} 1$ & $27.4 \pm 4.9$ & $27.2 \pm 5.3$ & 0.643 & $6.2 \pm 1.3$ & $5.9 \pm 1.1$ & 0.758 & $22.7 \pm 7.6$ & $23.4 \pm 6.2$ & 0.852 \\
\hline $\mathrm{T} 2$ & $32.3 \pm 3.8$ & $31.7 \pm 4.8$ & 0.582 & $5.1 \pm 1.5$ & $4.9 \pm 1.3$ & 0.652 & $18.4 \pm 6.7$ & $16.9 \pm 5.7$ & 0.547 \\
\hline T3 & $33.1 \pm 4.1$ & $32.6 \pm 5.1$ & 0.497 & $4.7 \pm 0.9$ & $5.1 \pm 1.6$ & 0.353 & $13.9 \pm 5.6$ & $13.5 \pm 5.8$ & 0.913 \\
\hline T4 & $34.2 \pm 4.4$ & $33.4 \pm 4.5$ & 0.754 & $3.9 \pm 1.2$ & $4.4 \pm 1.4$ & 0.215 & $14.1 \pm 4.4$ & $11.9 \pm 3.9$ & 0.426 \\
\hline T5 & $36.7 \pm 4.7$ & $35.3 \pm 4.2$ & 0.581 & $3.1 \pm 1.1$ & $3.5 \pm 0.9$ & 0.694 & $9.3 \pm 4.1$ & $8.7 \pm 4.1$ & 0.748 \\
\hline T6 & $37.5 \pm 5.2$ & $35.9 \pm 4.4$ & 0.464 & $3.8 \pm 1.1$ & $4.1 \pm 1.1$ & 0.831 & $10.2 \pm 4.2$ & $9.1 \pm 3.1$ & 0.864 \\
\hline $\mathrm{T7}$ & $40.3 \pm 5.6$ & $38.9 \pm 4.6$ & 0.362 & $4.2 \pm 0.8$ & $4.8 \pm 1.4$ & 0.757 & $13.1 \pm 3.5$ & $8.3 \pm 4.3$ & $0.025 *$ \\
\hline T8 & $40.9 \pm 4.6$ & $40.1 \pm 4.8$ & 0.814 & $4.1 \pm 1.2$ & $4.9 \pm 1.3$ & $0.031 *$ & $12.5 \pm 5.2$ & $7.6 \pm 4.4$ & $0.018^{*}$ \\
\hline T9 & $44.8 \pm 4.7$ & $41.1 \pm 5.1$ & $0.027^{*}$ & $4.1 \pm 0.9$ & $5.3 \pm 1.7$ & $0.024 *$ & $8.9 \pm 5.1$ & $7.8 \pm 4.2$ & 0.637 \\
\hline T10 & $42.7 \pm 4.3$ & $41.9 \pm 5.3$ & 0.295 & $4.8 \pm 1.2$ & $5.1 \pm 1.5$ & 0.684 & $9.1 \pm 5.5$ & $8.3 \pm 5.1$ & 0.592 \\
\hline T11 & $41.8 \pm 4.9$ & $40.7 \pm 5.8$ & 0.357 & $5.1 \pm 1.4$ & $5.4 \pm 1.6$ & 0.442 & $8.2 \pm 5.4$ & $7.5 \pm 5.3$ & 0.625 \\
\hline $\mathrm{T} 12$ & $42.6 \pm 7.2$ & $41.9 \pm 6.4$ & 0.625 & $5.3 \pm 1.6$ & $5.8 \pm 1.8$ & 0.517 & $7.8 \pm 7.2$ & $7.1 \pm 6.4$ & 0.694 \\
\hline L1 & $46.1 \pm 5.9$ & $44.8 \pm 5.7$ & 0.416 & $5.5 \pm 1.5$ & $5.7 \pm 1.2$ & 0.826 & $10.1 \pm 4.9$ & $8.8 \pm 5.1$ & 0.575 \\
\hline L2 & $49.4 \pm 6.2$ & $48.1 \pm 5.9$ & 0.246 & $5.8 \pm 1.6$ & $6.1 \pm 1.7$ & 0.627 & $11.2 \pm 5.2$ & $9.9 \pm 4.8$ & 0.835 \\
\hline L3 & $49.8 \pm 5.7$ & $47.1 \pm 6.1$ & $0.038 *$ & $6.5 \pm 1.7$ & $7.1 \pm 2.1$ & 0.793 & $13.8 \pm 5.8$ & $10.1 \pm 5.4$ & $0.037 *$ \\
\hline L4 & $49.1 \pm 5.8$ & $48.2 \pm 5.4$ & 0.321 & $7.8 \pm 2.1$ & $8.5 \pm 1.9$ & 0.817 & $12.5 \pm 6.1$ & $11.7 \pm 6.7$ & 0.621 \\
\hline L5 & $49.6 \pm 7.4$ & $49.1 \pm 6.8$ & 0.845 & $8.5 \pm 2.6$ & $9.2 \pm 2.3$ & 0.765 & $12.9 \pm 6.3$ & $11.5 \pm 6.9$ & 0.748 \\
\hline
\end{tabular}

\section{DISCUSSION}

Scoliosis is a three-dimensional deformity in which vertebral morphometry can differ from patient to patient, especially due to individual inter- and intravertebral rotation ${ }^{9}$. In order to perform safe pedicle screw instrumentation vertebral morphometry of every patient should be evaluated throughly. CT is the ideal imaging modality for detailed analysis of bone structure and good correlation has been shown between CT-based and true anatomic vertebral measurements ${ }^{10}$. In this study we report the results of CT analyses of AIS patients based on chord length, transverse pedicle width and angle.

The chord length is the distance from the most outer posterior cortex of the pedicle to the anterior cortex of the vertebral body with its the long axis of the pedicle in the transverse plane. It represents the maximum length that a screw can be inserted into a pedicle. Krag et al. ${ }^{11}$ recommended insertion of pedicle screws between 80 and $100 \%$ of the chord length for optimal resistance to pullout forces. Optimal sized pedicle screws also provide improved resistance to cyclic loading and derotational forces ${ }^{12,13}$. In order to perform the maneuvers for the correcti- on of scoliosis more effectively and safely, a strong screw-vertebra interface with optimally long pedicle screws is essential. On the other hand extremely long pedicle screws beyond the anterior vertebral cortex may endanger visceral and vascular structures $^{14}$. So, it is critical to know the chord length of each level to make an appropriate preoperative planning and perform safe pedicle screw instrumentation and correction maneuvers. In our study chord lengths on the concave side were slightly longer than the corresponding convex pedicle, especially at T9 and L3 levels, with a significant difference between. This finding of longer concave chord lengths was consistent with previous studies ${ }^{4,15}$. This difference may be related to the asymmetrical growth of the scoliotic spine which causes intravertebral rotation. Since the rotation in transverse plane is mostly at the apex of the deformity, we may have found significant difference at $\mathrm{T} 9$ and $\mathrm{L} 3$, which are generally the apices of thoracic and lumbar curves.

Another important parameter to be considered during pedicle screw instrumentation is the transverse pedicle width. The narrowest diameter of each pedicle should be known in order to choose the pedicle screw with the appropriate diameter. Screws with 
larger diameter than the pedicles may violate medial and lateral walls, whereas smaller diameter screws may cause failure due to pull-out mechanism. We found concave pedicles to be thinner than the convex side at most of the levels, however the difference was insignificant except T8 and T9 levels. Morphologic studies have shown that the thinnest pedicles are on the concave side of T3-T6 levels ${ }^{4,6,15}$. The narrowest pedicles were at T5 level in our study, which supports the findings of previous studies. Special care should be given at these levels in order not to perforate pedicle walls. Small diameter pedicle screws should be available. If the pedicles are extremely narrow, skipping these levels without instrumentation or using extrapedicular instrumentation may be an option.

Transverse pedicle angle values showed some variations between previous studies, most probably due to the varying pedicle entry points ${ }^{3-8}$. We found decreasing transverse pedicle angles in the thoracic region, with lowest values at T12, and increasing angles in lumbar region. Values on the concave side were slightly higher than the convex side, with significant difference at T7, T8 and L3 levels, which may be related to the intravertebral rotation at the apical regions. Knowing the sites of extreme rotation is important to find the best screw trajectory and to use the chord length effectively. If a direct trajectory cannot be found due to intravertebral rotation, again extrapedicular fixation with "in-out-in" technique may be used $^{6}$.

$\mathrm{CT}$ is one of the best imaging modalities to show the bone structure. Measurements can be performed on different planes. Since scoliosis is a three dimensional deformity, the true axial plane of each vertebra is mostly an oblique plane. In order to measure the parameters in these oblique plane, reconstructions should be performed, which necessitate the use of multiplanar CT with thin cuts. This is especially important in severe deformities, where vertebrae are highly tilted in coronal and sagittal planes. We used multiplanar CT and $0.6 \mathrm{~mm}$ cuts were taken throughout the thoracic and lumbar vertebrae, which enabled us to reconstruct the true axial plane of each vertebra.
Limitations of this study are the lack of both sagittal plane measurements and also comparisons with normal population. Reproducibility of the measurement technique may be questionable due to the difficulties in determining the true axial plane. On the other hand a similar group of patients with the same diagnosis and similar age group were evaluated. All parameters were measured digitally by the same observer and the same software program. Number of patients in this study were higher relative to previous morphologic studies.

In order to safely perform the pedicle screw instrumentation and the correction maneuvers in the scoliotic spine, morphology of each vertebral level should be known throughly since it can show variations among patients. Routine preoperative CT examination can give this important information about the individual bone structure of each patient.

\section{REFERENCES}

1. Asghar J, Samdani AF, Pahys JM, et al. Computed tomography evaluation of rotation correction in adolescent idiopathic scoliosis. A comparison of an all pedicle screw construct versus a hook-rod system. Spine. 2009;34:804-7. http//dx.doi.org/ 10.1097/BRS.0b013e3181996c1b.

2. Larson AN, Polly DW Jr, Diamond B, et al. Does higher anchor density result in increased curve correction and improved clinical outcomes in adolescent idiopathic scoliosis? Spine. 2014;39:571-8.

http//dx.doi.org/ 10.1097/BRS.0000000000000204.

3. Singh R, Srivastva SK, Prasath CS, et al. Morphometric measurements of cadaveric thoracic spine in Indian population and its clinical applications. Asian Spine J. 2011;5:20-34. http//dx.doi.org/ 10.4184/asj.2011.5.1.20.

4. Liljenqvist UR, Link TM, Halm HF. Morphometric analysis of thoracic and lumbar vertebrae in idiopathic scoliosis. Spine. 2000;25:1247-53.

5. Takeshita K, Maruyama T, Chikuda H, et al. Diameter, length, and direction of pedicle screws for scoliotic spine: analysis by multiplanar reconstruction of computed tomography. Spine. 2009;34:798-803. http//dx.doi.org/ 10.1007/s00586-010-1298-9.

6. Upendra B, Meena D, Kandwal P, et al. Pedicle morphometry in patients with adolescent idiopathic scoliosis. Indian J Orthop. 2010;44:169-76. http//dx.doi.org/ 10.4103/0019-5413.62084.

7. Kuraishi S, Takahashi J, Hirabayashi H, et al. Pedicle morphology using computed tomography-based navigation system in adolescent idiopathic scoliosis. J Spinal Disord Tech. 2013;26:22-8. http//dx.doi.org/ 10.1097/BSD.0b013e31823162ef.

8. Hong JY, Suh SW, Easwar TR, et al. Clinical anatomy of vertebrae in scoliosis: global analysis in four different diseases 
by multiplanar reconstructive computed tomography. Spine. J 2013;13:1510-20.

http//dx.doi.org/ 10.1016/j.spinee.2013.06.047.

9. Lee SM, Suk SI, Chung ER. Direct vertebral rotation: a new technique of three-dimensional deformity correction with segmental pedicle screw fixation in adolescent idiopathic scoliosis. Spine. 2004;29:343-9.

10. Misenhimer GR, Peek RD, Wiltse LL, et al. Anatomic analysis of pedicle cortical and cancellous diameter as related to screw size. Spine. 1989;14:367-72.

11. Krag MH, Beynnon BD, Pope $\mathrm{MH}$, et al. Depth of insertion of transpedicular vertebral screws into human vertebrae: effect upon screw-vertebra interface strength. J Spinal Disord. 1988;1:287-94.
12. Zindrick MR, Wiltse LL, Widell EH, et al. A biomechanical study of intrapeduncular screw fixation in the lumbosacral spine. Clin Orthop Relat Res. 1986;203:99-112.

13. Bezer M, Ketenci IE, Saygi B, et al. Bicortical versus unicortical pedicle screws in direct vertebral rotation: an in vitro experimental study. J Spinal Disord Tech. 2012;25:E178-82. http//dx.doi.org/ 10.1097/BSD.0b013e31825dd542.

14. Liljenqvist UR, Halm HF, Link TM. Pedicle screw instrumentation of the thoracic spine in idiopathic scoliosis. Spine. 1997;22:2239-45.

15. Takeshita K, Maruyama T, Chikuda H, et al. Diameter, length, and direction of pedicle screws for scoliotic spine: analysis by multiplanar reconstruction of computed tomography. Spine. 2009;34:798-803.

http//dx.doi.org/ 10.1097/BRS.0b013e3181895c36. 